McCollum, K. R., L. Powell, A. Snyman, M. Bomberger Brown, and J. Carroll. 2018. Kori Bustards (Ardeotis kori) respond to vegetation density and elevation in the Northern Tuli Game Reserve, Botswana. Avian Conservation and Ecology 13(1):13. https://doi.org/10.5751/ACE-01191-130113 Copyright (C) 2018 by the author(s). Published here under license by the Resilience Alliance.

Research Paper

\title{
Kori Bustards (Ardeotis kori) respond to vegetation density and elevation in the Northern Tuli Game Reserve, Botswana
}

\author{
Kathryn R. McCollum ${ }^{1}$, Larkin A. Powell ${ }^{1}$, Andrei Snyman ${ }^{2}$, Mary Bomberger Brown $^{1}$ and John P. Carroll ${ }^{1}$ \\ ${ }^{1}$ School of Natural Resources, University of Nebraska, Lincoln, Nebraska, USA, ${ }^{2}$ Mashatu Research, Northern Tuli Game Reserve, \\ Botswana
}

\begin{abstract}
Conservation planning and decision making for species of concern requires precise information on abundance and habitat associations. We conducted transect surveys throughout the Northern Tuli Game Reserve, Botswana during June-July 2014 and MayJuly 2015 to estimate the occupancy and abundance of Kori Bustards (Ardeotis kori). The probability of occupancy of Kori Bustards was greater in areas with tree canopy cover $\leq 50 \%(\psi 2014=0.37, \mathrm{SE} \pm 0.09 ; \psi 2015=0.39, \mathrm{SE} \pm 0.06)$ when compared with areas with tree canopy cover $>50 \%(\psi 2014=0.00, \mathrm{SE} \pm 0.00 ; \psi 2015=0.00, \mathrm{SE} \pm 0.00)$. Densities of Kori Bustards ranged from $0.03-5.02$ individuals $/ \mathrm{km}^{2}$ at our study sites. They showed annual variation, and densities were highest in areas where vegetation was classified as sparse or bare soil. Areas at low ( $\leq 540 \mathrm{~m}$ above sea level) and high ( $\geq 540 \mathrm{~m}$ above sea level) elevations at our study sites also exhibited differences in density of Kori Bustards but elevational differences varied among years. Areas categorized as both sparse vegetation and higher elevation had the highest estimated densities in 2014 with 5.02 individuals $/ \mathrm{km}^{2}$. Areas categorized as sparse vegetation and lower elevation had the highest densities in 2015 with 2.20 individuals $/ \mathrm{km}^{2}$. Our study demonstrates that areas of sparse vegetation and open canopy areas are important to Kori Bustards. However, open canopy areas outside of reserves may be at risk of conversion to row crop and other forms of agriculture as human populations and demands for food increase. Habitat-specific information will be useful for future studies to identify risks during landscape conservation planning within the range of the Kori Bustard.
\end{abstract}

\section{L'abondance de l'Outarde kori (Ardeotis kori) varie selon la végétation et l'élévation dans la réserve de chasse de Northern Tuli, Botswana}

RÉSUMÉ. La planification de la conservation et la prise de décisions pour les espèces préoccupantes requièrent des données précises sur leur abondance et leurs associations avec l'habitat. Nous avons effectué des relevés par transects dans la réserve de chasse de Northern Tuli, au Botswana, en juin-juillet 2014 et mai-juillet 2015, afin de déterminer l'occurrence et la densité d'Outardes kori (Ardeotis kori). La probabilité d'occurrence des outardes était supérieure dans les endroits où la voûte forestière couvrait $\leq 50 \%(\psi 2014=0,37$, écarttype $\pm 0,09 ; \psi 2015=0,39$, écart-type $\pm 0,06)$ comparativement aux endroits où la voûte couvrait $>50 \%(\psi 2014=0,00$, écart-type $\pm 0,00 ; \psi 2015=0,00$, écart-type $\pm 0,00$ ). Les densités de cette outarde s'élevaient de 0,03 à 5,02 individus $/ \mathrm{km}^{2}$ dans nos sites d'étude. Les densités montraient des variations annuelles et étaient plus élevées dans les endroits où la végétation était classée comme « éparse » ou « sol nu ». Les densités ont aussi différé selon les endroits de basse ( $\leq 540 \mathrm{~m}$ au-dessus du niveau de la mer) ou de haute ( $\geq 540 \mathrm{~m}$ ASL) élévation dans nos sites d'étude, et ces différences ont varié entre les années. Les endroits classés à la fois comme de végétation éparse et de haute élévation ont hébergé les densités les plus élevées en 2014, soit 5,02 individus/ $\mathrm{km}^{2}$. Les endroits classés à la fois comme de végétation éparse et de basse élévation ont hébergé les densités les plus élevées en 2015, soit 2,20 individus/ $\mathrm{km}^{2}$. Notre étude indique que les endroits de végétation éparse et ceux où la voûte est ouverte sont importants pour les Outardes kori. Toutefois, les endroits où la voûte forestière est ouverte à l'extérieur des réserves risquent peut-être d'être affectés à la culture en rangs ou à d'autres formes d'agriculture considérant que la population humaine et la demande alimentaire augmentent. Les données relatives à l'habitat seront utiles pour les éventuelles recherches visant à identifier les risques au moment de la planification de la conservation du paysage dans l'aire de répartition de l'Outarde kori.

Key Words: conservation; density estimation; distance sampling; occupancy analysis

\section{INTRODUCTION}

Habitat degradation and fragmentation negatively impact many species through the loss of access to critical resources (Fischer and Lindenmayer 2007, Jetz et al. 2007). A better understanding of the resources and land types most necessary to support a species in an environment can be useful for conservation efforts. Contemporary analysis methods for wildlife monitoring such as occupancy surveys and estimation of relative densities can provide a more complete understanding of both species distribution and abundance within a study area (MacKenzie and Nichols 2004). This information can be especially valuable for understudied and elusive species. We show the utility of contemporary analysis methods to better understand the habitat utilization and relative densities of an understudied species, the Kori Bustard (Ardeotis kori). The determination of which ecological covariates have influence on Kori Bustard habitat usage 
allows for improved conservation of the species, as well as other species that rely on and utilize similar landcover types.

Kori Bustards are large birds in the Family Otididae native to eastern and southern Africa (Johnsgard 1991, Senyatso 2011). Kori Bustards have the distinction of being, by some measures, the heaviest flying bird species in the world (Liebenberg 2000). The southern subspecies of the Kori Bustard (Ardeotis kori kori) is found throughout Zimbabwe, Botswana, southern Angola, Namibia, South Africa, and southern Mozambique (Johnsgard 1991), and is one of the national birds of Botswana. The other subspecies, Ardeotis kori struthiunculus, is found in eastern Africa from Ethiopia south to central Tanzania and Lake Victoria (Johnsgard 1991). Kori bustards are open grassland and open woodland species that are generally found in flat landscapes with medium to heavy grass cover in areas with some rocky outcrops (Johnsgard 1991, Osborne and Osborne 2001). There are few visual differences between male and female Kori Bustards, the most prominent being size, which can also be variable based on habitat quality, making sex identification difficult. They are usually found alone or in pairs and as such are generally considered a low-density species, but where food is readily available they can become gregarious (Liebenberg 2000, Senyatso 2011). Home range size varies seasonally, with ranges becoming smaller during the dry season and larger during the wet season (Senyatso 2011).

Habitat degradation and fragmentation have led to a reduction in the number of this once very common bird, especially outside major game reserves (Herremans 1998, Sinclair et al. 2002). Since the early 1900s, the range of the Kori Bustard has decreased by $8 \%$ in southern Africa and the number of individuals within the range has greatly decreased over this time (Senyatso et al. 2013). The species is considered near threatened on the IUCN Red List (BirdLife International 2016) and the South African red data book classifies Kori Bustards as vulnerable (Brooke 1984). Kori Bustards' low tolerance of human activity and their low reproduction rates during dry years have compounded these declining population trends (Herremans 1998, Osborne and Osborne 2001, Lichtenberg and Hallager 2008). Other threats to the species include collisions with powerlines (Martin and Shaw 2010, Shaw et al. 2010), poaching, and predation (Senyatso et al. 2013).

Our goal with this study was to better understand the factors that influence occupancy and density of Kori Bustards within a human-impacted landscape in northern Botswana. Kori Bustards receive varying levels of protection throughout their distribution, ranging from full protection in reserves to no regulation in other areas (Senyatso 2011, McCollum 2015). Kori Bustards have cultural significance with the local people (Low 2011) and are beneficial for the local ecotourism industry by attracting bird watchers to the area. Basic population and life history information are needed to better understand the threats to the conservation of Kori Bustards and to develop suitable management strategies. To gather more precise and detailed information about Kori Bustards in a cost-effective way within the study area, we conducted both occupancy and density surveys. Kori Bustards are a widespread low-density species (Johnsgard 1991, Senyatso 2013). The utilization of both occupancy and density analyses allows for the collection of information not only about what habitats the species may occupy, but also an estimate of how many individuals the local population consists of. In our study, we used occupancy analysis to determine which areas within our study area were more likely to be occupied by Kori Bustards, and utilized density estimations to gather more detailed information on the relative abundance of Kori Bustards within areas more likely to be occupied. The benefits of performing both occupancy and density surveys on a species for baseline information that could later be applied to population monitoring and conservation work have been shown by Gaston (1999). Linden et al. (2017) show that the use of occupancy surveys can give similar results to more expensive processes. Our specific objectives with this study were to determine the effects of different habitats on the occupancy and density of Kori Bustards.

\section{METHODS}

\section{Study area}

The Northern Tuli Game Reserve $\left(22^{\circ} 06{ }^{\prime} 57.3^{\prime \prime S} 29^{\circ} 05^{\prime} 25.4^{\prime \prime} \mathrm{E}\right)$ is a $720 \mathrm{~km}^{2}$ predominately unfenced protected area located in the northeastern corner of Botswana (Forssman 2013, McCollum 2015, Snyman et al. 2015; Fig. 1). The Northern Tuli Game Reserve was established as a nature reserve in the mid-1960s when landholders combined their properties into one large reserve as part of a conservation effort (Snyman 2010, McCollum 2015). Prior to the reserve's formation, much of the land was used for row crop agriculture and grazing livestock (Selier 2008). The Northern Tuli Game Reserve is now used for ecotourism and research purposes with multiple ecotourism lodges in the areas surrounding it (Snyman 2010), and Kori Bustards are an important attraction to ecotourists. Little to no habitat management is performed in the area, which allows for natural habitat development and change. The two largest contributors to habitat change since the reserve was established are natural seasonal flooding and high elephant density (Selier 2008). Flooding influences local seed banks, and has led to the introduction of different plant species near rivers. Elephant populations aid in sustaining sparse vegetation and open canopy areas through feeding and movement (O'Connor et al. 2007).

The eastern park boundary follows the Shashe River, the southern reserve boundary follows the Limpopo River, the western boundary is marked by a foot-and-mouth disease fence, and the southwestern boundary is marked by a fence along the Motloutse River. Privately owned hunting farms are found east of the park, and the land to the west and south are farming areas used for agricultural crops and communal lands used for grazing goats and cattle (Selier 2008, McCollum 2015). The northern boundary follows along the Tuli Circle $\left(21^{\circ} 58^{\prime} 24.2^{\prime \prime S} 29^{\circ} 08^{\prime} 06.7^{\prime \prime E}\right)$ in Zimbabwe, which is a hunting concession managed by the Zimbabwean National Parks and Wildlife Department. Wildlife movements between the Tuli Circle and the reserve are unrestricted (McCollum 2015, Snyman et al. 2015). A ban on commercial wildlife hunting was put into place in January 2014 (Government of Botswana 2014). Effects of the hunting ban on wildlife populations is as yet unknown. Poaching is a common problem in Botswana and surrounding areas, affecting all types of wildlife (Senyatso 2011). A variety of habitats exist within the Northern Tuli Game Reserve, providing an opportunity to compare which landscape features affect Kori Bustard occupancy and density. Habitats within the Northern Tuli Game Reserve fall into five categories based on vegetation density, water, and canopy 
Fig. 1. Kori Bustard (Ardeotis kori) detection points throughout the Northern Tuli Game Reserve, Botswana from June-July 2014 and May-July 2015. Two specified areas, EcoTraining and Central, were the only regions sampled.

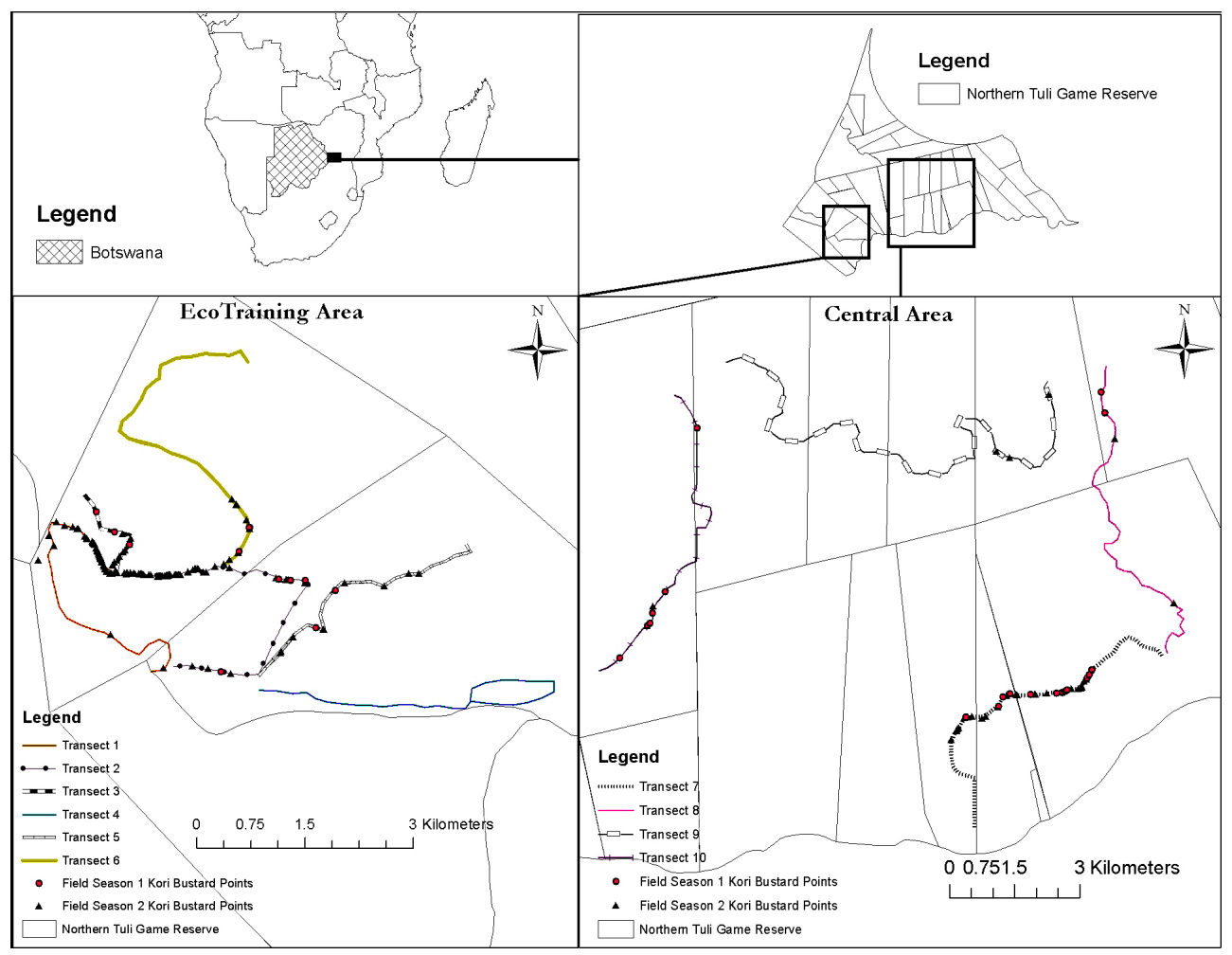

cover; Bare Soil, Sparse Vegetation, Grassy/Woody, Dense Vegetation/Woodland, and Water (see McCollum 2015 for details). The landscapes within the Northern Tuli Game Reserve are unique in their combination of agricultural and wild, undeveloped areas, providing ideal conditions to study the effects of anthropogenic changes on wildlife (Selier 2008). To date, no studies have been conducted on Kori Bustards or similar species in our study area.

\section{Survey methods}

We performed line transect sampling along 10 transects throughout the study area (Fig. 1; see McCollum 2015 for details). The sample area included two regions: EcoTraining, which consisted of six transects located near the EcoTraining camp; and Central, which consisted of four transects in the middle of the reserve (Fig. 1; see McCollum 2015 for details). The Central transects were closer to the tourism lodges in the Northern Tuli Game Reserve, and had more tourists and vehicles compared to the EcoTraining transects. Transects ranged in length from 1.48 $\mathrm{km}$ to $14.45 \mathrm{~km}$, depending on the length of drivable track (Fig. 1; see McCollum 2015 for details). Transects were established during 2014 along pre-existing roads, following reserve regulations to have as little impact on the surrounding environment and landscape as possible. The variation in transect length and location is likely to have had little impact on our ability to detect Kori Bustards because we sampled each area that included each habitat category proportionally to the amount present in the Northern Tuli Game Reserve (see McCollum 2015 for details; Table 1). Routes included all habitat categories within the reserve to be representative of the area. Each of the 10 transects were split into approximately 1000-meter sections to provide more detailed environmental classifications.

Table 1. Proportion of habitat types sampled compared to overall amount of habitat type determined from vegetation layers in ArcGIS (version 10.3.1) within the Northern Tuli Game Reserve, Botswana.

\begin{tabular}{lccc}
\hline \hline Habitat Type & $\begin{array}{c}\text { Area } \\
\text { Sampled } \\
\left(\mathrm{km}^{2}\right)\end{array}$ & $\begin{array}{c}\text { Area } \\
\text { Available } \\
\left(\mathrm{km}^{2}\right)\end{array}$ & $\begin{array}{c}\text { Proportion of } \\
\text { Available Area } \\
\text { Sampled }\end{array}$ \\
\hline Bare Soil & 7.25 & 89.21 & 0.08 \\
Sparse Vegetation & 43.26 & 410.16 & 0.11 \\
Grassy/Woody & 11.75 & 169.93 & 0.10 \\
$\begin{array}{l}\text { Dense Vegetation / } \\
\text { Woodland }\end{array}$ & 10.05 & 52.10 & 0.19 \\
\hline
\end{tabular}

Transects were surveyed every one to three days at varying times of the day ranging from 06:45CAT (sunrise) to 17:30CAT (sunset) and in random order within each region to prevent time bias. All surveys were completed during June-July 2014 for year 1 and May-July 2015 for year 2 . To minimize bias, all data were collected by, or in the presence of, one individual (KRM). As each transect was surveyed, we recorded the number of Kori Bustards detected and a sighting of one or more Kori Bustards was considered a detection. At each detection a GPS point was created using a 
handheld GPS unit (Garmin 60CSX, Garmin International, Inc., Olathe, KS, USA) and recorded with a unique individual ID. The distance of the sighted individual was measured from a point perpendicular to the transect using a handheld laser rangefinder (Nikon Monarch Laser 800, Nikon Inc., Melville, NY, USA). Flushing was accounted for by measuring distance to the point where the individual was first seen, not where the individual was when the vehicle was perpendicular to the point on the transect. Kori bustards are generally solitary, however when seen in groups (two or more individuals within $15 \mathrm{~m}$ of each other) the point of distance was measured to the center of the group. The number of individuals was recorded, as well as canopy openness, transect and section number, and habitat description to address the assumptions of heterogeneity in occupancy and detectability.

\section{Occupancy analysis}

Occupancy analyses are useful because they consider the detection probability of the species of interest (MacKenzie et al. 2003) while considering the issue of imperfect detection. The goal is to estimate the proportion of sampling units containing animals, as opposed to abundance estimates that estimate the number of animals within a particular sampling area (Royle and Nichols 2003). The estimation of occupancy is useful for rare and elusive species in which surveys may routinely fail to detect the species (MacKenzie et al. 2003) and allow the evaluation of ecological dynamics when abundance is low.

We used program PRESENCE (MacKenzie et al. 2002, 2003) to obtain occupancy and detection probabilities for four of the habitats found in the Northern Tuli Game Reserve: Bare Soil, Sparse Vegetation, Grassy/Woody, and Dense Vegetation/ Woodland. Categorical variables were used to examine basic landscape factors with practical data collected in the field during our surveys. We focused on two covariates for the occupancy analysis: canopy cover and vegetation density. Canopy cover was evaluated as two categories: open (if $\geq 50 \%$ of area was not shaded by trees $>2$ meters in height) and closed (if $\geq 50 \%$ of area was covered by trees $>2$ meters in height). Vegetation density was designated into two categories with the use of ArcGIS (version 10.3.1) and an existing land cover database for our study site (see McCollum 2015 for details). Areas in existing maps of the reserve that were labeled as Dense Vegetation/Woody and Grassy/Woody were considered "dense" and areas labeled Sparse Vegetation and Bare Soil were considered "sparse" (McCollum 2015). Therefore, occupancy and detection probabilities were obtained for open canopy, closed canopy, sparse vegetation, and dense vegetation individually.

We chose to use a single-season occupancy model developed by MacKenzie et al. (2002) and run each year as a separate model to follow the closure assumption for occupancy modeling. The closure assumption was met between transect sections by the length of segments $(1000 \mathrm{~m})$. Kori Bustards are thought to have smaller home ranges during the dry season (Senyatso 2011). Given that our surveys were performed during the dry season each year, it is unlikely that individuals moved away from or between transects while the study was taking place. Therefore, we used a single-season model instead of a multiseason model because change in occupancy between years was not a primary objective of our study. Every completed survey of a section of a transect was considered a unique occupancy occasion (see McCollum 2015 for details). Each section was treated as an independent sampling unit with unique habitat covariates, and surveys were temporally replicated 11-26 times for a given site. We generated estimates of occupancy probability for each combination of vegetation, density, and canopy openness based on the parameter coefficients from the best-supported model. Transects in the Ecotraining region were surveyed more often than those in the Central region because of logistical constraints. The same types of habitat were sampled in both regions, therefore the difference in repetition between the two regions should have no impact on the results. We avoided sampling the same transect multiple times on the same day during the same time period to meet the assumptions of independence among sites and surveys. Counts for each section were converted to binary data for the occupancy analysis, with a " 1 " representing detection and a " 0 " representing no detection.

We first considered four models for both years individually (20142015) to determine which covariates affected probability of Kori Bustard detection (p): $\psi() p.($ canopy) to assess the effect of canopy on detection probability; $\psi$ (.)p(vegetation) to assess the effect of sparse or dense vegetation on detection; $\psi(.) \mathrm{p}($.$) as a null model$ (no effects); and $\psi() p.(t)$ to determine if there was any surveyspecific influence, i.e., if survey order influenced detection. We then utilized the top model from the detection probability set and considered four models for both years to determine which covariates affected the probability of Kori Bustard occupancy $(\psi)$. For 2014 we considered the following models: $\psi$ (canopy)p (canopy) to assess the effect of canopy on occupancy with canopy influence on detection probability incorporated; $\psi$ (vegetation)p (canopy) to determine effect of sparse or dense vegetation on occupancy with canopy influence on detection probability incorporated; $\psi$ (.)p(canopy) to assess the effect of canopy on detection probability; and $\psi() p.($.) as a null model (no effects; Table 2). For 2015 we considered the following models: $\psi$ (canopy) $\mathrm{p}$ (vegetation) to assess the effect of canopy on occupancy with vegetation influence on detection probability incorporated; $\psi$ (vegetation)p(vegetation) to determine effect of sparse or dense vegetation on occupancy with vegetation influence on detection probability incorporated; $\psi$ (.)p(vegetation) to assess the effect of sparse or dense vegetation on detection probability; and $\psi() p.($. as a null model (no effects; Table 2). A model was determined to be influential if it had a $\triangle \mathrm{AIC}<2$ (MacKenzie et al. 2002). We estimated the overall probability of detecting the species at a site during the set of replicate surveys, as $p^{*}$ given $1-(1-p)^{n}$ where $n$ is the number of replicated surveys. We calculated $\mathrm{p}^{*}$ from our estimates of $p$ in the top model for 2014 and 2015 to determine the number of surveys needed to obtain $\mathrm{p}^{*}=0.90$ (Fig. 2).

\section{Density estimation}

We utilized program DISTANCE (Buckland et al. 2001) to analyze the transect data to determine the density of Kori Bustards within the Northern Tuli Game Reserve. We supplemented the occupancy analysis with density estimation to provide another dimension of habitat dynamics at our study site. The usefulness of these analytical tools to understand the presence-abundance relationship of species has been recognized (Gaston 1999, Linden et al. 2017). By performing density estimation in addition to occupancy analyses, we accounted for higher populations and had the ability to detect more variation associated with covariates than we would otherwise have been able to determine. 
Table 2. Occupancy $(\psi)$ and detection (p) model selection results for Kori Bustard (Ardeotis kori) in the Northern Tuli Game Reserve, Botswana during June-July 2014 and May-July 2015. Each year was considered separately. K represents number of parameters. $\triangle \mathrm{AIC}$ represents difference between model and best-fitting model (model with lowest AIC).

\begin{tabular}{|c|c|c|c|c|c|}
\hline Year & Model & $\mathrm{K}$ & $\mathrm{AIC}^{\dagger}$ & $\Delta \mathrm{AIC}$ & AIC weight \\
\hline \multicolumn{6}{|l|}{2014} \\
\hline & $\psi(.) \mathrm{p}$ (canopy) & 4 & 267.54 & 0.00 & 0.45 \\
\hline & $\psi(.) \mathrm{p}()$. & 2 & 267.64 & 0.10 & 0.43 \\
\hline & $\psi$ (vegetation) $\mathrm{p}$ (canopy) & 6 & 271.42 & 3.88 & 0.06 \\
\hline & $\psi$ (canopy) $\mathrm{p}$ (canopy) & 6 & 271.54 & 4.00 & 0.06 \\
\hline & $\psi(.) \mathrm{p}(\mathrm{t})$ & 21 & 292.74 & 25.20 & 0.00 \\
\hline \multicolumn{6}{|l|}{2015} \\
\hline & $\psi$ (canopy) $\mathrm{p}$ (vegetation) & 6 & 653.69 & 0.00 & 0.62 \\
\hline & $\Psi(.) \mathrm{p}$ (vegetation) & 4 & 655.05 & 1.36 & 0.32 \\
\hline & $\psi($ vegetation $) \mathrm{p}$ (vegetation) & 6 & 658.98 & 5.29 & 0.04 \\
\hline & $\psi(.) \mathrm{p}()$. & 2 & 660.88 & 7.19 & 0.02 \\
\hline & $\psi(.) \mathrm{p}(\mathrm{t})$ & 27 & 693.64 & 39.95 & 0.00 \\
\hline
\end{tabular}

†Akaike’s Information Criterion

Fig. 2. Overall probability of detecting Kori Bustards (Ardeotis kori) at a site at least once during the set of replicate surveys (represented by $\mathrm{p}^{*}$, given $\left.\mathrm{p}^{*}=1-(1-\mathrm{p})^{\wedge} \mathrm{n}\right)$ during two field seasons in June-July 2014 ( $\mathrm{p}=0.08)$ and May-July $2015(\mathrm{p}=$ 0.26) in the Northern Tuli Game Reserve, Botswana.

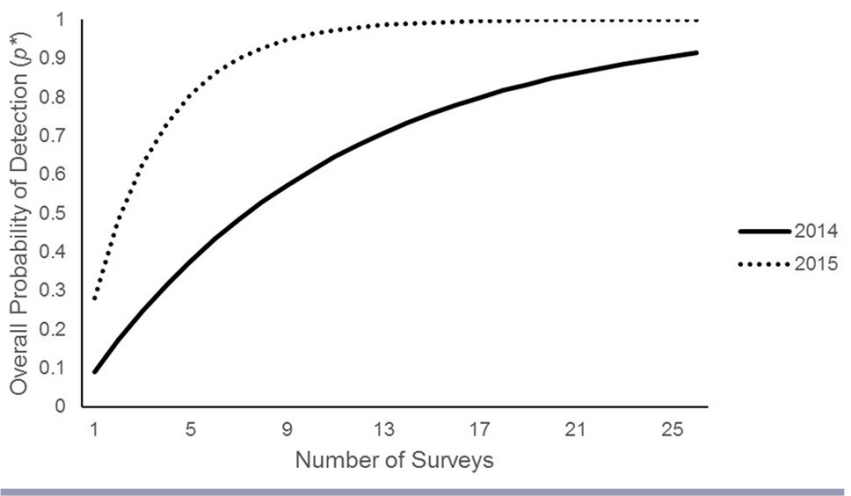

We classified all surveyed transect sections according to four habitat categories, which were similar to those used for the occupancy analyses. We classified vegetation density as "sparse" or "dense," just as with the occupancy analysis with the use of ArcGIS (version 10.3.1; see McCollum 2015 for details). Elevation was split into two categories: upper (elevations $\geq 540$ meters above sea level); and lower (elevations $\leq 540$ meters above sea level); 540 meters was the median point of the range of elevations (lowest elevation: 500 meters above sea level; highest elevation: 580 meters above sea level) encountered across the 10 transects. Elevation was split at this point to allow categorical analysis of this continuous variable to determine if elevation influenced kori bustard density. The combination of vegetation density and elevation resulted in four different strata, or regions, in the set of transects we sampled. We allowed for different patterns of detection among strata (Buckland et. al 2001) in program DISTANCE, and density was determined based on effective strip width (Buckland et al. 2001; Tables 3 and 4).
Table 3. Density model selection within program DISTANCE for Kori Bustards (Ardeotis kori) in each habitat type surveyed JuneJuly 2014 and May-July 2015 within the Northern Tuli Game Reserve, Botswana. All detection models run with cosine adjustment.

\begin{tabular}{lccl}
\hline \hline Year & Habitat Category & Model AIC & Detection Model \\
\hline 2014 & Dense Lower & 50.37 & Uniform key \\
2014 & Dense Lower & 51.18 & Negative Exponential key \\
2014 & Dense Lower & 51.74 & Half-normal key \\
2014 & Dense Lower & 52.09 & Hazard-rate key \\
2014 & Dense Upper & 0.00 & Half-normal key \\
2014 & Dense Upper & 10.39 & Uniform key \\
2014 & Dense Upper & $--\$$ & Hazard-rate key \\
2014 & Dense Upper & $--\$$ & Negative Exponential key \\
2014 & Sparse Lower & 191.02 & Hazard-rate key \\
2014 & Sparse Lower & 191.18 & Negative Exponential key \\
2014 & Sparse Lower & 192.19 & Half-normal key \\
2014 & Sparse Lower & 193.09 & Uniform key \\
2014 & Sparse Upper & 74.90 & Hazard-rate key \\
2014 & Sparse Upper & 75.46 & Negative Exponential key \\
2014 & Sparse Upper & 75.95 & Uniform key \\
2014 & Sparse Upper & 76.62 & Half-normal key \\
2015 & Dense Lower & 115.69 & Uniform key \\
2015 & Dense Lower & 117.16 & Half-normal key \\
2015 & Dense Lower & 117.39 & Negative Exponential key \\
2015 & Dense Lower & 118.86 & Hazard-rate key \\
2015 & Dense Upper & 15.80 & Uniform key \\
2015 & Dense Upper & 17.81 & Half-normal key \\
2015 & Dense Upper & 17.81 & Negative Exponential key \\
2015 & Dense Upper & $--\$$ & Hazard-rate key \\
2015 & Sparse Lower & 1893.2 & Uniform key \\
2015 & Sparse Lower & 1893.3 & Half-normal key \\
2015 & Sparse Lower & 1894.7 & Hazard-rate key \\
2015 & Sparse Lower & 1895.2 & Negative Exponential key \\
2015 & Sparse Upper & 171.71 & Uniform key \\
2015 & Sparse Upper & 172.21 & Half-normal key \\
2015 & Sparse Upper & 172.36 & Negative Exponential key \\
2015 & Sparse Upper & 174.15 & Hazard-rate key \\
\hline Akaike’s Information Criterion & & \\
Too few observations to fit to model. & \\
& & & \\
\hline & & & \\
\hline
\end{tabular}


Table 4. Density estimates (individuals $/ \mathrm{km}^{2}$ ) for Kori Bustards (Ardeotis kori) in each habitat type surveyed June-July 2014 and MayJuly 2015 within the Northern Tuli Game Reserve, Botswana. All selected detection models run with cosine adjustment.

\begin{tabular}{|c|c|c|c|c|c|c|c|}
\hline Year & $\begin{array}{l}\text { Habitat } \\
\text { Category }\end{array}$ & $\begin{array}{l}\text { Effective Strip } \\
\text { Width (meter) }\end{array}$ & $\begin{array}{l}\text { Density (individuals/ } \\
\mathrm{km}^{2} \text { ) }\end{array}$ & $\begin{array}{c}\text { Selected Detection } \\
\text { Model }\end{array}$ & $95 \% \mathrm{CI}$ & $\begin{array}{l}\text { GOF } \\
\text { P value }\end{array}$ & $\% \mathrm{CV}$ \\
\hline \multicolumn{8}{|l|}{2014} \\
\hline & Dense Lower & 154.00 & 0.19 & Uniform key & $0.08-0.46$ & 0.18 & 47.07 \\
\hline & Dense Upper & 180.00 & 0.03 & Half-normal key & $0.01-0.14$ & $--^{\dagger}$ & 100 \\
\hline & Sparse Lower & 61.83 & 0.65 & Hazard-rate key & $0.25-1.65$ & 0.61 & 49.24 \\
\hline & Sparse Upper & 5.63 & 5.03 & Hazard-rate key & $1.04-24.24$ & $--^{\dagger}$ & 81.37 \\
\hline \multicolumn{8}{|l|}{2015} \\
\hline & Dense Lower & 124.00 & 0.65 & Uniform key & $0.34-1.25$ & 0.86 & 33.78 \\
\hline & Dense Upper & 52.00 & 0.32 & Uniform key & $0.079-1.34$ & 1.00 & 77.82 \\
\hline & Sparse Lower & 123.49 & 2.20 & Uniform key & $1.73-2.80$ & 0.52 & 12.27 \\
\hline & Sparse Upper & 214.00 & 0.13 & Uniform key & $0.07-0.24$ & 0.74 & 31.56 \\
\hline
\end{tabular}

${ }^{\dagger}$ Cells had sample sizes too small to calculate GOF P values.

We used four estimators to determine the detection model of best fit for each habitat category based on the data: uniform, halfnormal, hazard-rate, and negative exponential. Models were evaluated using Akaike's Information Criterion (AIC; Buckland et al. 2001; Table 3). The detection model with the lowest AIC score was considered the best fit and was used to determine estimated density of individuals within that specific habitat category. For example, of the four detection models tested, the uniform key model was selected by the program as the model that best fit the Dense Lower habitat category of 2014 (Tables 3 and 4). Models were also evaluated using the Kolmogorov-Smirnov goodness-of-fit (GOF) test, with models having $\mathrm{P}>0.05$ considered well-fitted to the data (Buckland et al. 2001).

\section{RESULTS}

\section{Occupancy analysis}

Kori Bustards were observed on 31 occasions over 18 transect sections in 2014 and on 129 occasions over 25 transect sections in 2015 within the Northern Tuli Game Reserve. There were 1126 surveys per section, dependent on transect and field season. The naive occupancy, or the proportion of sites where Kori Bustards were detected, was low for both years (2014: 0.25, 2015: 0.35 ). Detection did not vary as a factor of survey period because the model with time-specific detection probability was well below the null model in ranking among our models considered to evaluate variation of detection probability (2014: $\triangle \mathrm{AIC}=25.2$, 2015: $\triangle \mathrm{AIC}=38.6$ ). Therefore, we did not include time as a surveyspecific factor for detection in our exploration of occupancy models. Kori Bustard detection probability was shown to be most influenced by canopy closure in 2014 (null model: $\triangle \mathrm{AIC}=0.10$, $\psi(.) \mathrm{p}$ (vegetation): $\triangle \mathrm{AIC}=4.04)$ and vegetation density in 2015 $(\psi$ (.) $\mathrm{p}$ (canopy): $\triangle \mathrm{AIC}=3.54$, null model: $\triangle \mathrm{AIC}=5.83$ ). Therefore, detection as a factor of canopy was incorporated into each occupancy probability model in 2014 and detection as a factor of vegetation was incorporated in 2015 (Table 2).

In 2014, all models were less descriptive of Kori Bustard occupancy probability than the null model with the detection factor incorporated for that year, $\psi($.$) p(canopy), and the overall$ null model $\psi(.) \mathrm{p}($.$) (Table 2). In 2015, we found that Kori Bustard$ probability of occupancy was influenced by canopy (Table 2). Occupancy probability in closed canopy was $0.0(\mathrm{SE} \pm 0.0)$, while occupancy in open sites was 0.39 ( $\mathrm{SE} \pm 0.06,95 \% \mathrm{CI}: 0.28-0.52$ ). Probability of detection in the top model (Table 2) was 0.09 (SE \pm 0.02 ) in 2014 and 0.28 (SE \pm 0.02$)$ in 2015. We found that between eight (in 2014) and 25 (in 2015) repeated surveys were required to reach a cumulative detection probability $\left(\mathrm{p}^{*}\right)$ for the species of 0.90 (Fig. 2).

\section{Density estimation}

We recorded 34 observations of Kori Bustards by sampling 987.12 $\mathrm{km}$ of transect in 2014 and 208 observations of Kori Bustards by sampling $1133.54 \mathrm{~km}$ of transect in 2015 (Fig. 1). Densities of Kori Bustards throughout the region ranged from $0.02-5.02 / \mathrm{km}^{2}$ throughout both field seasons according to the results from the analysis performed in program DISTANCE (Table 4). Kori Bustard densities were highest in 2014 in areas of sparse vegetation at higher elevations and lowest in areas of dense vegetation at upper elevation (Table 4). In 2015 highest densities were found in areas of sparse vegetation at lower elevations and lowest in areas of sparse vegetation at upper elevations (Table 4). We found that vegetation had an impact on density, with areas of sparse vegetation having higher density estimations than areas of dense vegetation (Table 4). Elevation had less of an impact on density, as shown by the upper elevation having higher estimates in 2014 and the lower elevation having higher estimates in 2015 (Table 4).

\section{DISCUSSION}

\section{Occupancy analysis}

Our occupancy analysis suggests Kori Bustard occupancy and detection probability could be influenced by both canopy and vegetation. In both years, the canopy covariate had an effect on occupancy rates and detection probability of Kori Bustards, suggesting they used less-forested areas with fewer trees with large canopies compared to areas with more trees and closed canopies. Areas with open canopy had the greatest occupancy estimates and areas with closed canopies had no observations of Kori Bustards in either year. Low occupancy levels are expected for Kori Bustards because they are noted to be a widespread species (Johnsgard 1991, Liebenberg 2000, Senyatso 2011).

The choice of open canopy and open landscape environments may occur for multiple reasons, such as easier maneuverability or 
favored foraging (Johnsgard 1991). Kori Bustards are by some measures the heaviest flying birds in the world (Liebenberg 2000) and require more room for take-off and landing than other avian species. Areas of open canopies allow individuals the space to take flight and to land with less risk of injury than areas of denser vegetation. Food accessibility would influence Kori Bustard occupancy in one habitat over another (Johnsgard 1991). Areas of sparse vegetation may be more plentiful in the amount of food sources available to Kori Bustards, which would in turn increase their occupancy in those areas.

Vegetation type was shown to not play an important role in Kori Bustard occupancy in our study area because no models with these covariates had $\triangle \mathrm{AIC}<2$. There was also shown to be no survey-specific influence, with $\psi() p.(t)$ coming last in the model rankings. However, vegetation type was shown to influence detection probability in 2015, with the model of $\psi$ (canopy)p (vegetation) found as the top model for that year (Table 2). The influence of vegetation type on detection probability could be due to a few factors. Variance in vegetation growth and plant type may be because of a difference in rainfall between the two sample years. This could affect the ability to see birds between years, which could alter counts.

\section{Density estimation}

Our density estimates suggest Kori Bustards were most abundant in areas of sparse vegetation and upper elevations. In both years, habitat with the highest estimated density of Kori Bustards was that classified as having sparse vegetation. This suggests the habitats with thinner understory vegetation would have higher numbers of Kori Bustard when compared to habitats with thicker understory vegetation (Table 4). Sparsely vegetated understory could be preferred over thicker understory because of a need for space to take flight. Sparse vegetation could also be used by the prey species, such as rodents, lizards, and insects, which utilize the vegetation found in less dense areas. Changes in elevation across our study area are associated with changes in vegetation type, which could also impact food availability. As previously stated, Kori Bustard movement is highly influenced by food availability, and areas with more food would most likely have higher densities of individuals. There is no current research available on Kori Bustard home range size in habitats like those found in the Northern Tuli Game Reserve, but territory size of males and females could influence the number of Kori bustards found in suitable areas. Our distance-based results coincide with our results from the occupancy analysis, suggesting that areas with higher probability of occupancy are also areas more likely to have higher densities of Kori Bustards.

The overall low density of Kori Bustards throughout the study area is a characteristic that has been previously observed in other populations of this species (Liebenberg 2000, Senyatso 2011). Although there were fewer individuals observed in 2014 than 2015, we were still able to obtain density estimates for 2014. The difference in the number of detections between the two field seasons raises the question of what factors not included in this study such as rainfall and resource availability outside of the study area may be influencing large-scale distribution of Kori Bustards. There are only approximately $200 \mathrm{~km}$ of sparse upper-elevation habitat available to be surveyed in our study area. To improve the rigor of density estimates it would be useful to sample an even larger area than what was available to us (Buckland et al. 2001). Future studies should acquire more detections to gain more insight into habitat selection by Kori Bustards in similar vegetation and cover types. Kori Bustards have been shown to be a widespread low-density species, so higher detections could be obtained by surveying larger portions of each vegetation and cover type.

\section{Implications}

We determined, with occupancy and abundance estimates, that Kori Bustards used areas where canopies were at least $50 \%$ open with either bare soil or sparse vegetation. One of the implications of occupancy-abundance relationships to species conservation is that species with low abundance and low occupancy may be at higher risk of local extinction than species with greater abundance and occupancy. We found that Kori Bustards in the Northern Tuli Game Reserve exhibited low occupancy with a probability below 0.50 in both years of surveys, and low abundance with density estimations at 5.02 individuals $/ \mathrm{km}^{2}$ in 2014 and 2.20 individuals/ $\mathrm{km}^{2}$ in 2015. Senyatso et al. (2011) reports the Kori Bustard is declining throughout its range, which supports the need for protected areas like the Northern Tuli Game Reserve for refuge. Certainly, species with relative low density and low occupancy, such as we report for the Kori Bustard, may be less likely to survive change to local habitat. With the threat of surrounding habitat loss from agriculture, we encourage biologists in the reserve to prioritize conservation of the grasslands with available sparse vegetation and open canopy habitat. Our density estimates and occupancy levels can be compared to estimates from other systems as they become available to further evaluate spatial and temporal dynamics of Kori Bustard populations.

There was a notable difference in detections of Kori Bustard between the two years, with only 34 detections in 2014 compared to 129 detections in 2015. Both surveys were completed during the winter months, after the wet season, within the study area (year 1 from June-July 2014, year 2 from May-July 2015). The differences between the years seemed to rely on rainfall, with 2014 representing an average year for timing of rainfall and 2015 having a late rain at the end of the wet season. The later rain in 2015 caused vegetation to persist late into the fall and winter, which could have allowed for longer foraging opportunities for Kori Bustards. Kori Bustard movement is highly influenced by food availability (Johnsgard 1991, Senyatso 2011). However, we acknowledge that these trends are found in a relatively short study of only two years, with the sample size of one year being much greater (and therefore more robust) than the other. The difference in detections most likely had an effect on the model selections as well, which could explain differences in model rankings among years (Table 3).

The habitats occupied by Kori Bustards are also those habitats with vegetation density typically utilized for cattle grazing throughout African savannas (Börner et al. 2007, Lukomska et al. 2014). With cattle as one of the top agricultural exports of the country of Botswana (Bahta et al. 2015), this conflict could become a significant issue as space becomes more limited and land use change occurs. One of the largest impacts on wildlife caused by cattle grazing in this environment is bush encroachment (Senyatso 2011). Bush encroachment is defined by Lukomska et al. (2014:3) as "the persisting occurrence of an ecosystem state 
dominated by woody vegetation." Poor cattle grazing practices such as overstocking cattle and the suppression of bushfires can lead to an increase in bush encroachment, which in turn can lead to a loss of green grass biomass (Lukomska et al. 2014). Although it has not been studied in the Northern Tuli Game Reserve, bush encroachment is a major issue in other parts of the Kori Bustard's range for both livestock and wildlife (Börner et al. 2007, Senyatso 2011). Our results show that Kori Bustards use sparse vegetation with open canopy over dense vegetation with closed canopy (Table 4), which are landcover types that would decrease as bush encroachment increases. This could lead to a lack of spatial resources for Kori Bustards and other species that utilize similar resources.

\section{CONCLUSION}

Sub-Saharan Africa contains a substantial portion of arable land (Jenkins 2003), and as demands for food increase with the increasing human populations, so will the pressures to utilize all available lands for agricultural purposes. The easiest lands to convert are those with already open canopies and sparse vegetation, which are the same as those shown to be used by Kori Bustards. Kori Bustards are known to have low tolerance for human activity and would most likely avoid areas of agriculture and human development instead of adapting to the change in habitat (Herremans 1998, Osborne and Osborne 2001, Lichtenberg and Hallager 2008).

Our study illustrates a covariate affecting both the density and space utilization of the Kori Bustard in a landscape consisting of a matrix of land uses. Occupancy of Kori Bustards was influenced by canopy, with open canopy used more than closed canopy. Kori Bustards were found at higher densities in areas of sparse vegetation. Kori Bustards were recently identified by the IUCN as "near threatened" status due to loss of habitat and population decline (BirdLife International 2016), so any information helpful in the development of future conservation and management plans for the species and its habitats is valuable. To support Kori Bustard populations in habitats like those found in the Northern Tuli Game Reserve, emphasis should be placed on the preservation of open canopy areas with sparse vegetation throughout their range. These findings could be variable depending on habitat, therefore more studies of this nature are crucial in the continued preservation of this species. This could be accomplished through the conservation of these habitats and the avoidance of conversion of land use to agricultural fields or livestock grazing.

Responses to this article can be read online at: http://www.ace-eco.org/issues/responses.php/1191

\section{Acknowledgments:}

Funding was provided by The Wilson Ornithological Society, The Cooper Ornithological Society, the University of NebraskaLincoln's School of Natural Resources' Graduate Student Association Travel Grant, the Irvin A. and Agnes E. Nelson fellowship, and crowd-sourced donations. We would like to thank the landowners and board of the Mashatu Game Reserve and the Northern Tuli Game Reserve for their support, the Republic of
Botswana's Ministry of Environment, Wildlife and Tourism, and the Department of Wildlife and National Parks for their permission to work in Botswana. We also thank EcoTraining, Inc. for their care and support throughout this project. Finally, we would like to acknowledge the hard work of our field assistants including the University of Georgia and University of Nebraska-Lincoln study abroad courses from 2014 and 2015, as well as all of the EcoTraining volunteers, students, staff, guides, and instructors throughout both of the field seasons.

\section{LITERATURE CITED}

Bahta, S., D. Baker, P. Malope, and H. Katijuongua. 2015. A metafrontier analysis of determinants of technical efficiency in beef farm types: an application to Botswana. Paper presented at the 29th International Conference of Agricultural Economists, Milan, Italy, 8-14 August.

BirdLife International. 2016. Ardeotis kori. The IUCN Red List of Threatened Species 2016: e.T22691928A93329549. http://dx. doi.org/10.2305/IUCN.UK.2016-3.RLTS.T22691928A93329549. en

Börner, J., S. I. Higgins, J. Kantelhardt, and S. Scheiter. 2007. Rainfall or price variability: what determines rangeland management decisions? A simulation optimization approach to South African savannas. Agricultural Economics 37(2-3):189-200. http://dx.doi.org/10.1111/j.1574-0862.2007.00265.x

Brooke, R. 1984. South African red data book - birds. Report of the Committee for Nature Conservation Research in the National Programme for Environmental Sciences. South African National Scientific Programmes Report 97 Foundation for Research Development, Council for Scientific and Industrial Research, Pretoria, SA.

Buckland, S. T., D. R. Anderson, K. P. Burnham, J. L. Laake, D. L. Borchers, and L. Thomas. 2001. Introduction to distance sampling: estimating abundance of biological populations. Oxford University Press, New York, New York, USA.

Fischer, J., and D. B. Lindenmayer. 2007. Landscape modification and habitat fragmentation: a synthesis. Global Ecology and Biogeography 16(3):265-280. http://dx.doi.org/10.1111/

j.1466-8238.2007.00287.x

Forssman, T. 2013. A preliminary report on fieldwork in the Northern Tuli Game Reserve, northeastern Botswana. South African Archaeological Bulletin 68(197):63-71.

Gaston, K. J. 1999. Implications of interspecific and intraspecific abundance-occupancy relationships. Oikos 86(2):195-207. http:// dx.doi.org/10.2307/3546438

Government of Botswana. 2014. Hunting ban takes effect. Republic of Botswana, Gaborone, Botswana. [online] URL: http://www.gov.bw/en/News/HUNTING-BAN-TAKES-EFFECT/

Herremans, M. 1998. Conservation status of birds in Botswana in relation to land use. Biological Conservation 86(2):139-160. http://dx.doi.org/10.1016/S0006-3207(98)00016-0

Jenkins, M. 2003. Prospects for biodiversity. Science 302 (5648):1175-1177. http://dx.doi.org/10.1126/science.1088666 
Jetz, W., D. S. Wilcove, and A. P. Dobson. 2007. Projected impacts of climate and land-use change on the global diversity of birds. PLoS Biology 5(6):e157. http://dx.doi.org/10.1371/journal. pbio.0050157

Johnsgard, P. A. 1991. Bustards, hemipodes, and sandgrouse: birds of dry places. Oxford University Press, New York, New York, USA.

Lichtenberg, E. M., and S. Hallager. 2008. A description of commonly observed behaviors for the Kori Bustard (Ardeotis kori). Journal of Ethology 26(1):17-34. http://dx.doi.org/10.1007/ s10164-006-0030-Z

Liebenberg, L. 2000. Tracks and tracking in Southern Africa. Struik Nature, Cape Town, Southern Africa.

Linden, D. W., A. K. Fuller, J. A. Royle, and M. P. Hare. 2017. Examining the occupancy-density relationship for a low-density carnivore. Journal of Applied Ecology 54(6):2043-2052. http://dx. doi.org/10.1111/1365-2664.12883

Low, C. 2011. Birds and KhoeSān: linking spirits and healing with day-to-day life. Africa 81(2):295-313. http://dx.doi.org/10.1017/ S0001972011000027

Lukomska, N., M. F. Quaas, and S. Baumgärtner. 2014. Bush encroachment control and risk management in semi-arid rangelands. Journal of Environmental Management 145:24-34. http://dx.doi.org/10.1016/j.jenvman.2014.06.005

MacKenzie, D. I., and J. D. Nichols. 2004. Occupancy as a surrogate for abundance estimation. Animal Biodiversity and Conservation 27.1:461-467.

MacKenzie, D. I., J. D. Nichols, J. E. Hines, M. G. Knutson, and A. B. Franklin. 2003. Estimating site occupancy, colonization, and local extinction when a species is detected imperfectly. Ecology 84(8):2200-2207. http://dx.doi.org/10.1890/02-3090

MacKenzie, D. I., J. D. Nichols, G. B. Lachman, S. Droege, J. A. Royle, and C. A. Langtimm. 2002. Estimating site occupancy rates when detection probabilities are less than one. Ecology 83 (8):2248-2255. http://dx.doi.org/10.1890/0012-9658(2002)083[2248: ESORWD]2.0.CO;2

Martin, G. R., and J. M. Shaw. 2010. Bird collisions with power lines: failing to see the way ahead? Biological Conservation 143 (11):2695-2702. http://dx.doi.org/10.1016/j.biocon.2010.07.014

McCollum, K. 2015. Occupancy analysis and density estimation of Kori Bustard (Ardeotis kori) and Helmeted Guineafowl (Numida meleagris) for use in landscape conservation planning in the Northern Tuli Game Reserve, Botswana. University of Nebraska-Lincoln, Lincoln, Nebraska, USA. [online] URL: http://digitalcommons.unl.edu/natresdiss/126/

O'Connor, T. G., P. S. Goodman, and B. Clegg. 2007. A functional hypothesis of the threat of local extirpation of woody plant species by elephant in Africa. Biological Conservation 136 (3):329-345. http://dx.doi.org/10.1016/j.biocon.2006.12.014

Osborne, T., and L. Osborne. 2001. Annual research report for the Ministry of Environment and Tourism. Ministry of Environment and Tourism. Windhoek, Namibia.

Royle, J. A., and J. D. Nichols. 2003. Estimating abundance from repeated presence-absence data or point counts. Ecology 84 (3):777-790. http://dx.doi.org/10.1890/0012-9658(2003)084[0777: EAFRPA]2.0.CO;2

Selier, S.-A. J. 2008. The social structure, distribution and demographic status of the African elephant population in the Central Limpopo River Valley of Botswana, Zimbabwe and South Africa. University of Pretoria, Pretoria, South Africa.

Senyatso, K. 2011. Conserving widely distributed wildlife species in an African savanna: parks, cattle-grazing and communitymanaged areas. University of East Anglia, Norfolk, UK.

Senyatso, K. J., N. J. Collar, and P. M. Dolman. 2013. Assessing range-wide conservation status change in an unmonitored widespread African bird species. Diversity and Distributions 19 (2):106-119. doi:10.1111/j.1472-4642.2012.00909.x http://dx.doi. org/10.1111/j.1472-4642.2012.00909.x

Shaw, J. M., A. R. Jenkins, P. G. Ryan, and J. J. Smallie. 2010. A preliminary survey of avian mortality on power lines in the Overberg, South Africa. Ostrich 81(2):109-113. http://dx.doi. org/10.2989/00306525.2010.488421

Sinclair, I., P. Hockey, and W. Tarboton. 2002. Birds of Southern Africa. Third edition. Princeton University Press, Princeton, New Jersey, USA.

Snyman, A. 2010. Lion (Panthera leo) social organisation in a human affected landscape. Tshwane University of Technology, Pretoria, South Africa.

Snyman, A., C. R. Jackson and P. J. Funston. 2015. The effects of alternative forms of hunting on the social organization of two small populations of lions Panthera leo in southern Africa. Oryx 49(4):604-610. http://dx.doi.org/10.1017/S0030605313001336
Editor-in-Chief: Keith A.Hobson

Subject Editor: Erik Blomberg
Sponsored by the Society of Canadian Ornithologists and Bird Studies Canada Parrainée par la Société des ornithologistes du Canada et Études d'oiseaux Canada

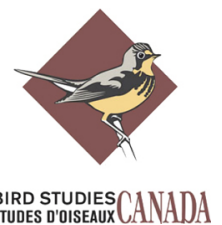

